\title{
Pembinaan Jurnalistik untuk Meningkatkan Minat Menulis pada Santri di Dayah Darul Muta'alimin Meulaboh
}

\author{
Reni Juliani', Putri Maulina ${ }^{2}$ \\ 1,2Prodi Ilmu Komunikasi, Universitas Teuku Umar \\ Email: renijuliani@utu.ac.id, \\ Email: putrimaulina@utu.ac.id
}

\begin{abstract}
Santri (student) also plays an important role in writing to convey information about Islamic teachings. For this reason, students need knowledge of journalism in order to develop their intellectual potential. Therefore, journalistic guidance needs to be carried out to increase student interest in writing. This is useful for teaching students how good journalism is and based on journalistic principles. The result of this nonprofit activity was that Students of Dayah Darul Muta'alimin learned about real journalism, they knew how good the news was, and they realized that facts and data must be guaranteed to be true.
\end{abstract}

Keywords: Journalism; Interest; Writing.

\begin{abstract}
Abstrak
Santri juga memiliki peran penting melalui tulisannya untuk menyampaikan informasi tentang ajaran agama Islam. Untuk itu, para santri membutuhkan pengetahuan tentang jurnalistik untuk dapat mengembangkan potensi intelektual yang dimiliki oleh santri tersebut. Oleh sebab itu pembinaan jurnalistik untuk meningkatkan minat menulis santri perlu dilakukan. Hal ini berguna untuk memberikan pemahaman kepada santri bagaimana jurnalistik yang baik dan berdasarkan pada kaidah jurnalistik. Hasil yang dicapai melalui kegiatan pengabdian masyarakat ini adalah Santri Dayah Darul Muta'alimin menjadi mengenal jurnalistik sebenarnya, mereka mengetahui bagaimana berita yang baik dan menjadi sadar bahwa fakta dan data harus dijamin kebenarannya.
\end{abstract}

Kata Kunci: Jurnalistik; Minat; Menulis.

\section{PENDAHULUAN}

Apabila melirik historis pendirian pesantren di Indonesia, Lembaga pendidikan agama ini sebenarnya telah ada sejak dulu sehingga lembaga ini disebut lembaga pendidikan tertua di Indonesia. Pada masa penjajahan, pesantren pada masa itu telah mencetak pemuka agama yang tidak hanya berperan untuk menyiarkan agama Islam ke seluruh pelosok Indonesia, namun juga berperan dalam membantu para pejuang dalam melawan penjajah.

Setelah Indonesia merdeka, pesantren tetap eksis di dunia pendidikan. Terlebih pada zaman modern seperti ini, banyak orang tua resah mengingat dunia yang semakin sekuler dan liberal dikarenakan begitu mudahnya budaya lain masuk dan mempengaruhi generasi muda kita. 
Hal ini yang menyebabkan animo masyarakat yang sangat besar untuk menyekolahkan anak mereka ke pesantren. Dan hal ini juga yang mengakibatkan pondok pesantren jumlahnya semakin meningkat seantero negeri.

Dalam perjalanan panjang pendirian pesantren di Indonesia. Pesantren melahirkan berbagai tradisi yang menjadi ciri-ciri pendidikan pondok pesantren. Salah satu ciri khasnya adalah dakwah. Dakwah merupakan salah satu cara para ulama dalam menyampaikan informasi keagamaan kepada pengikut mereka. Sehingga tulis menulis atau jurnalistik menjadi tradisi yang dibangun di pesantren. Melalui jurnalistik, informasi dakwah dapat disebarkan dengan cepat dan jangkauannya luas.

Pramoedya Ananta Toer mengatakan bahwa "Orang boleh pandai setinggi langit, tapi selama ia tidak menulis, ia akan hilang di dalam masyarakat dan dari sejarah. Menulis adalah bekerja untuk keabadian." Sehingga dapat kita ambil kesimpulan bahwa jika di dunia ini tulisan hilang maka hilanglah sejarah di kehidupan kita, hal ini dikarenakan tidak ada yang menulis dan mencatat sejarah tersebut sedangkan ingatan kita begitu terbatas untuk mengingat sejarah.
Dunia tulis menulis merupakan elemen yang sangat pesat perkembangannya. Makin banyaknya berita televisi, surat kabar, media online, bahkan situs jejaring merupakan bukti logis yang terlihat nyata di kehidupan seharihari. Tanpa kita sadari, kita sebagai manusia sudah sangat dekat dengan dunia jurnalistik. Walau tidak sebagai pekerja media, kita bisa jadi menjadi penikmat media bahkan bisa menjadi citizen journalism yang diberi kesempatan untuk mencari, mengolah dan menyebarkan berita di media massa. Siapapun bisa berkecimpung dalam jurnalistik, tanpa memandang usia, latar belakang pendidikan, agama maupun budaya. Bahkan, dewasa ini jurnalistik sudah digandrungi oleh remaja, termasuk santri.

Santri, salah satu komponen di dunia pendidikan Indonesia yang tidak bisa dipisahkan, kini dituntut untuk memiliki peran yang lebih dari sekedar mengkaji kitab kuning. Santri juga memiliki peran penting dalam penyampaian informasi tentang ajaran agama Islam. Untuk itu, para santri membutuhkan pengetahuan tentang jurnalistik untuk dapat mengembangkan potensi intelektual yang dimiliki oleh santri tersebut. Santri tidak melulu harus siap belajar agama saja akan tetapi santri juga harus siap menerima ilmu umum seperti 
jurnalistik agar kedua ilmu tersebut seimbang karena santri mempunyai peran penting yaitu untuk menyebarkan ajaran islam ke masyarakat luas. Oleh karenanya santri dituntut untuk bisa menguasai teknologi informasi dan komunikasi, termasuk media cetak. Meskipun kehidupan santri hanya bergelut di sekitar pesantren saja tetapi kemajuan teknologi informasi tidak boleh dipisahkan begitu saja.

Salah seorang wartawan senior pernah berkata: "Jika Anda ingin eksisting jadilah pembalap, jika Anda ingin kaya jadilah Bankir, tapi jika Anda ingin duduk di antara orang-orang yang membuat sejarah, jadilah wartawan", sebuah ungkapan menggetarkan yang layak direnungkan para wartawan, bahwa mereka bukanlah kuli tinta, tapi pembuat sejarah yang tidak harus manut pada redaksi seperti kerbau yang dicocok hidungnya (Hikmat, 2018:90).

Oleh sebab itu pembinaan jurnalistik untuk meningkatkan minat menulis santri di Dayah Darul Muta'alimin Meulaboh perlu dilakukan. Hal ini berguna untuk memberikan pemahaman kepada santri bagaimana jurnalistik yang baik dan berdasarkan pada kaidah jurnalistik. Hal ini dilakukan untuk melahirkan jurnalis santri yang tangguh, terampil, profesional dan bermoral, sehingga santri dapat bersaing dengan pelajar umum yang sudah terbiasa bergelut dengan dunia jurnalistik.

\section{METODE PELAKSANAAN}

Materi yang diberikan dalam pembinaan jurnalistik untuk meningkatkan minat menulis santri yang diadakan pada tanggal 16 Maret 2018 di Dayah Darul Muta'alimin Meulaboh menekankan pada pemahaman pentingnya mengetahui dasar-dasar jurnalistik dan berita-berita yang ditayangkan di media kepada santri di Dayah Darul Muta'alim Meulaboh. Santri diperkenalkan beberapa bentuk media, baik media cetak, radio, televisi,maupun media sosial lainnya. Kemudian santri dikenalkan teori dasar menulis jurnalistik yakni teori $5 \mathrm{~W}-1 \mathrm{H}$.

Pembinaan jurnalistik untuk meningkatkan minat menulis santri di Dayah Darul Muta'alimin Meulaboh perlu dilakukan agar santri di Dayah Darul Muta'alimin Meulaboh tidak hanya menguasai ilmu keagamaan semata. Tetapi, harus menguasai ilmu menulis dan jurnalistik sebagai ruang kreativitas dalam berdakwah. Dengan begitu, ruang-ruang publik maupun media sosial dapat diisi karya-karya tulis para santri di Dayah Darul Muta'alimin Meulaboh.

Kegiatan tersebut mempunyai harapan agar pembelajaran 
jurnalistik terus berlanjut. Dayah Darul Muta'alimin Meulaboh merupakan dayah yang terbilang baru. Dayah tersebut juga masih dalam

penyempurnaan

pembangunan. Oleh sebab itu sangat penting pengenalan awal mengenai jurnalistik untuk mengawali kreativitas menulis santri sehingga harapan ke depan Santri di Dayah Darul Muta'alimin Meulaboh sudah mempunyai ruang menulis sendiri seperti majalah dinding (mading).

\section{HASIL DAN PEMBAHASAN}

Jurnalistik atau dalam bahasa Inggris disebut journalisme mempunyai kata dasar yaitu journal, berarti catatan harian, atau catatan yang berisi kejadian atau fenomena sehari-hari, atau sering disebut surat kabar. Journal sediri sebenarnya berasal dari bahasa Latin diurnalis, berarti harian atau tiap hari. Bedasarkan kata tersebut maka lahirlah kata jurnalis, yaitu diartikas sebagai orang yang melakukan pekerjaan jurnalistik (Kusumaningrat dan Kusumaningrat, 2006: 15).

F. Fraser Bond menyatakan: "Journalism ambraces all the forms in which and trough wich the news and moment on the news reach the public". Jurnalistik adalah usaha segala bentuk yang membuat berita dan ulasan mengenai berita sampai pada kelompok pemerhati (Tahrun, Houtman dan Nasir, 2019:53).

Onong U. Effendi menjelaskan bahwa jurnalistik adalah keterampilan dalam mengolah bahan berita yang bersifat infromatif sejak dari peliputan (pengumpulan) hingga penyusunan yang layak kemudian disebarluaskan kepada khalayak (Tahrun, Houtman dan Nasir, 2019:53). Hal senada juga disampaikan Azwar (2018:5) dimana jurnalistik merupakan aktivitas mengumpulkan, mencari data, mengolah, dan menyusun data-data tersebut menjadi berita. Selain itu, dalam lingkup besar jurnalistik itu terdapat etika dalam pelaksanaannya. Jurnalistik juga akan bicara bagaimana pengelolaannya dan juga terkait teknik peliputan dan penulisan menjadi berita.

Berbicara mengenai etika. Etika merupakan sekelompok garis panduan yang dibentuk khusus untuk memantau perilaku manusia. Jurnalistik misalnya, merupakan salah satu bidang yang memerlukan etika untuk memastikan perilaku pengamalnya senantiasa berada dalam landasan yang betul. Etika bukannya undang-undang, yang mana ciri utama yang membedakan kedua-dua konsep ini ialah dampak dari kesalahan yang berbeda. Melanggar undang-undang akan 
menyebabkan seseorang itu akan dikenakan hukuman. Misalnya orang yang mencuri akan ditangkap polisi jika ia terbukti bersalah akan dipenjara. Orang yang melanggar etika pula tida akan dikenakan hukuman yang sedemikian, karena hakikatnya etika hanyalah garis panduan yang boleh dijadikan pedoman buat wartawan yang berhasrat mengharungi dunia jurnalisti (Syam, 2016:56-57).

Yuniati dan Rachmiati (2006:58) menyebutkan beberapa fungsi jurnalistik antara lain: untuk menyiarkan informasi, mendidik masyarakat, mempengaruhi dan menghibur.

Paul De Massenner menjelaskan bahwa berita merupakan informasi yang dianggap penting dan menarik minat khalayak. Charnley dan James M. Neal, menambahkan bahwa berita dapat disebut berupa laporan mengenai sebuah fenomena atau peristiwa yang terjadi di dalam masyarakat, bisa berupa pendapat pakar atau opini dalam memandang sebuah objek, kecenderungan, situasi, kondisi, interpretasi yang penting, menarik, up to date dan harus sesegera mungkin disampaikan kepada masyarakat (Sumadiria, 2005:64).

Tidak ada media tanpa berita, sebagaimana berita tanpa media. Sedangkan definisi berita menurut Humas adalah segala sesuatu yang hangat, faktual dan menarik perhatian sejumlah orang (Kriyantono, 2008:107).

Di antara syarat berita adalah sebagai berikut (Fitri, 2006):

1. Fakta, yaitu bahwa sebuah berita merupakan fakta, bukan karangan (fiksi) atau dibuat-buat.

2. Obyektif, yaitu berita harus sesuai dengan keadaan sebenarnya, tidak boleh dibumbui sehingga merugikan pihak yang diberitakan.

3. Berimbang, yaitu bahwa sebuah berita biasanya dianggap berimbang apabila wartawan atau reporter memberi informasi kepada pembacanya, pendengarnya atau pemirsanya tentang semua detail penting dari suatu kejadian dengan cara yang tepat.

4. Lengkap, yaitu dimana berita yang lengkap adalah berita yang memuat jawaban atas pertanyaan who, what, why, when, where, dan how $(5 \mathrm{~W}+1 \mathrm{H})$;

5. Akurat yaitu berita yang ditampilkan harus tepat, benar dan tidak terdapat kesalahan. Akurasi sangat berpengaruh pada penilaian kredibilitas media maupun reporter itu sendiri.

Pembinaan jurnalistik untuk meningkatkan minat menulis santri di Dayah Darul Muta'alimin Meulaboh merupakan pembinaan 
jurnalistik pertama yang pernah di lakukan di dayah tersebut.

Para santri di Dayah Darul Muta'alimin Meulaboh sangat antusias dan mengikuti kegiatan ini sampai selesai. Dari hasil pengamatan sebelum diadakannya pembinaan, santri hanya mengenai jurnalistik merupakan berita seperti berita di televisi, radio, koran dan juga media sosial. Setelah pembinaan dilakukan. Mereka memahami bahwa jurnalistik merupakan kegiatan mencari, mengumpulkan, mengolah dan menyiarkan berita. Selain itu dalam menulis berita, syarat dan ketentuan berlaku untuk menghasilkan berita yang baik dan bernilai berita (news value).

Para santri di Dayah Darul Muta'alimin Meulaboh diperkenalkan unsur-unsur dalam berita dimana unsur pokoknya adalah 5W+1H. Yaitu: who, what, why, when, where, dan how. Who adalah siapa pelaku, atau orang lain dari sebuah peristiwa yang terjadi. What adalah apa beritanya, mengenai hal apa, dan pertanyaan mengenai permasalahan atau hal yang terjadi pada suatu peristiwa. Why adalah penyebab terjadinya pertistiwa, mengenai alasan atau motivasi terjadinya sebuah peristiwa. When adalah pertanyaan-pertanyaan mengenai waktu terjadinya peristiwa, berita atau cerita yang terjadi. Where adalah di mana mengandung pertanyaan-pertanyaan mengenai tempat atau lokasi sebuah peristiwa terjadi. Sedangkan How adalah pertanyaan-pertanyaan yang mengandung cara atau proses berlangsungnya suatu peristiwa.

Charles A. Dana pada tahun 1982 menyebutkan hal yang menarik perihal berita. Dia mengatakan bahwa tidak dapat dikatakn berita apabila peristiwa yang terjadi seperti seekor anjing menggigit orang, namun berita tersebut dapat dikatakan apabila peristiwa yang terjadi seperti orang menggigit anjing (Assegaf, 1991:22). Pandangan Charles mengenai pemahaman sebuah berita sangat sempit, dia hanya memandang berita itu merupakan kejadian luarbiasa di luar kebiasaan yang terjadi sehingga unik dan menarik untuk disebarkan kepada khalayak. Batasan Charles ini sesungguhnya tidak benar. Sebuah informasi dapat dikatakan berita bukan saja melihat fenomena yang langka dan unit tapi juga menyangkut aktor yang ada di dalam beritanya. Jika yang digigit seekor anjing adalah seseorang yang sangat terkenal seperti Presiden atau artis maka itu tetap akan menjadi sebuah berita menari dan akan diminati oleh khalayak. Akan tetapi berita perihal tersebut tidak akan menjadi berita apabila tidak disiarkan oleh media. Mengingat media merupakan wadah dalam penyampaian pesan secara efektik dan efisien sehingga berita tersebut 
akan tetap menjadi berita apabila disampaikan pada waktu yang tepat (Assegaf, 1991:22).

Berita sudah seharusnya berkonten peristiwa yang dapat menarik perhatian pembaca. Tidak basi dan bersifat terkini. Hal ini dikarenakan tujuan dari pembuatan berita di media massa adalah agar didengar, ditonton ataupun dibaca oleh masyarakat. Berita wajib memiliki nilai yang dianggap penting oleh pembaca maupun penonton. Berita diharuskan mempunyai daya tarik, dan sebagainya.

Eriyanto (2002: 106-107) menjelaskan bahwa nilai berita sangat berperan dalam hal ini bukan saja menyangkut fenomena yang diangkat menjadi berita, melainkan bagaimana peristiwa tersebut diramu dan disajikan kepada khalayak. Ini menjadi tahapan pertama dari bagaimana peristiwa dikontruksi. Ukuranukuran yang digunakan untuk memilah sebuah fakta peristiwa oleh wartawan adalah ukuran profesional yang disebut sebagai nilai berita.

Dalam pembinaan ini, ditekankan pemahaman kepada santri bahwa fakta dan data sangat penting dalam menulis berita. Seorang wartawan sebelum menyiarkan berita wajib baginya untuk menverifikasi kembali berita yang telah ditulisnya. Diadakan check \& recheck terhadap fakta dan data bertujuan untuk menjamin kebenaran fakta.

Level kompetensi wartawan dapat dibagi menjadi tiga, antara lain (Nurudin, 2009:151):

1. Wartawan Yunior

Wartawan Yunior ditujukan kepada mereka yang memiliki pengalaman kerja kurang dari dua tahun. Mereka diharapkan mampu mencari dan mengumpulkan bahan berita serta menuliskannya menjadi naskah berita sesuai dengan petunjuk Wartawan Madya dan Wartawan Senior.

2. Wartawan Madya

Wartawan Madya adalah mereka yang memiliki pengalaman sebagai wartawan antara dua sampai tujuh tahun. Mereka dituntut mampu menilai bahan yang layak berita dan menuliskannya menjadi berita secara mandiri. Selain telah mampu menguasai hal-hal yang dipersyaratkan untuk Wartawan Yunior, Wartawan Madya idealnya mampu mengoordinasi tim peliputan berita, menilai bahan yang layak berita, dan menuliskannya menjadi berita secara mandiri sesuai dengan kebijakan media masing-masing.

3. Wartawan Senior

Wartawan Senior adalah
wartawan yang
berpengalaman dan
menguasai kompetensi yang


ada pada Wartawan Yunior dan Wartawan Madya. Ia juga dituntut untuk memiliki kemampuan memprediksi pemberitaan yang sesuai dengan perkembangan peristiwa, yang akan datang yang sesuai dengan kondisi sosial, politik, dan ekonomi yang berkembang di masyarakat.

Setelah penyampaian materi, santri diperkenalkan bagaimana menulis dan membaca berita.
Diadakan simulasi bagaiman menjadi citizen journalism.

Beberapa santri dipanggil ke depan untuk mempraktekkan langsung. Satu orang santri menjadi presenter, satu orang menjadi reporte dan satu orang lagi menjadi nara sumber. Kegiatan ini mengakhiri pembinaan jurnalistik untuk meningkatkan minat menulis santri di Dayah Darul Muta'alimin.

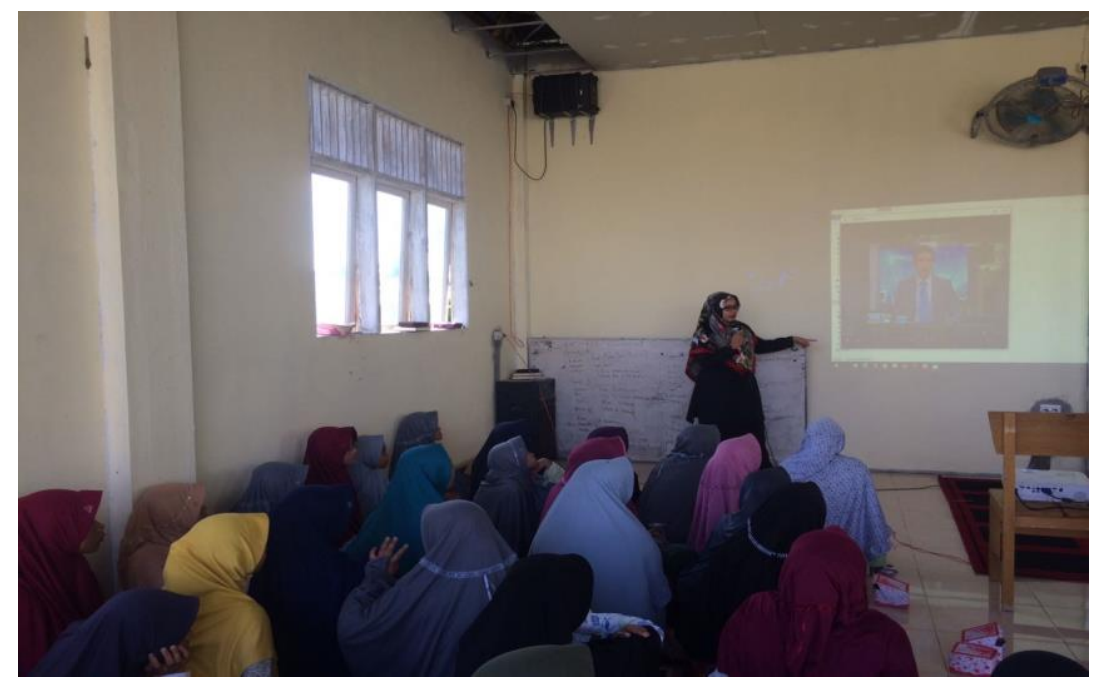

Gambar 1. Pemateri Memberikan Materi Jurnalitik Kepada Santri

\section{PENUTUP}

Hasil yang dicapai melalui kegiatan pengabdian masyarakat ini adalah sebagai berikut:

1. Santri Dayah Darul Muta'alimin Meulaboh menjadi mengenal jurnalistik sebenarnya.

2. Santri Dayah Darul Muta'alimin Meulaboh mengetahui bagaimana berita yang baik.

3. Santri Dayah Darul Muta'alimin Meulaboh menjadi sadar bahwa fakta dan data harus dijamin kebenarannya.

Berdasarkan hasil yang diperoleh dalam kegiatan pengabdian masyarakat ini, adapun saran yang bisa disampaikan yaitu 
Santri di Dayah Darul Muta'alimin Meulaboh sangat antusias terhadap materi pembinaan jurnalistik untuk meningkatkan minat menulis santri ini oleh sebab itu disarankan kepada Pimpinan Dayah Darul Muta'alimin Meulaboh untuk menyediakan ruang untuk mengembangkan kreativitas menulis santri seperti majalah dinding (mading).

\section{DAFTAR PUSTAKA}

Assegaf, Dja far. 1991. Jurnalistik Masa Kini. Bandung :PT Remaja Rosdakarya.

Azwar. 2018. 4 Pilar Jurnalistik: Pengetahuan Dasar Belajar Jurnalistik Edisi Pertama. Jakarta: Kencana.

Eriyanto.2001. Analisis Wacana Pengantar Analisis Teks Media. Yogyakarta: PT.LKiS Printing Cemerlang.

Fitri, Al. 2006. Teknik Sederhana Menulis Berita di Media Website. http://www.ptabandarlampung.go.id/artikelpengadilan/539-teknik-sederhanamenulis-berita-online-al-fitri-s-agsh-mhi.html. (diakses tanggal 31 Maret 2018).

Hikmat, Mahi M. 2018. Jurnalistik: Literary Journalism. Jakarta: Prenadamedia Group.

Kriyantono, Rachmat. 2008. Public Relations Writing: Media Public
Relations Membangun Citra Korporat. Jakarta: Kencana Prenada Media Group.

Kusumaningrat, Hikmat dan Kusumaningrat, Purnama. 2006. Jurnalistik Teori dan Praktik. Bandung: PT Remaja Rosdakarya.

Nurudin. 2009. Jurnalisme Masa Kini. Jakarta: Rajagrafindo Persada.

Sumadiria, AS Haris. 2005. Jurnalistik Indonesia: Menulis Berita dan Feature. Bandung: PT. Remaja Rosdakarya.

Syam, Hamdani M. 2016. Jurnalisme Damai: Memahasi Sistem Pemberitaan di Daerah Konflik. Yogyakarta: Samudra Biru.

Tahrun, Houtman dan Nasir, Muhammad. 2019. Keterampilan Pers dan Jurnalistik Berwawasan Jender. Yogyakarta: Deepublish.

Yuniati, Yenni dan Rachmiatie, Atie. 2006. Komitmen Wartawan Terhadap Jurnalistik Publik. Mimbar, Vol.XXII (1): 52-92. 